\title{
A comparative anatomical study of the genus Puschkinia Adams in Turkey
}

\author{
Kadriye Yetişen ${ }^{1 *}$, Hasan Yıldırım², Canan Özdemir ${ }^{1}$ \\ ${ }^{1}$ Department of Biology, Faculty of Art and Science, Celal Bayar University, Manisa, Turkey \\ ${ }^{2}$ Department of Biology, Faculty Science, Ege University, İzmir, Turkey
}

\begin{abstract}
In the study, Puschkinia scilloides Adams, P. bilgineri Yıldırım, and P. peshmenii Rix et B. Mathew were compared anatomically. Although the stem vascular bundles were arranged in two rows in P. peshmenii, they can observed in three rows in P. scilloides and P. bilgineri. In addition, some differences were found, such as the metaxylem number in the root, number of vascular bundles in the scape, presence of raphide crystals, and number of protruding epidermis cells at the tip of the leaf. These differences have been found to be taxonomically useful for distinguishing these species. Moreover, similarities and differences between Puschkinia Adams and the taxonomically closely related Scilla L. section Chionodoxa Boiss. and Scilla bifolia L. taxa were also discussed.
\end{abstract}

Keywords: anatomy, Puschkinia, Scilla, taxonomy, Turkey

\section{Introduction}

The genus Puschkinia is represented by three species in Turkey (P. scilloides Adams, P. peshmenii Rix et B. Mathew, and $P$. bilgineri Yildırım). The species of this genus show high morphological variations, especially $P$. scilloides (Edmondson 1984, Yildırım 2012, 2013, 2014). These species are distributed naturally in Turkey. Puschkinia scilloides is distributed in north Caucasus, Lebanon, northern Iran, Iraq and Syria (Rix and Mathew 2007, Ylldırım 2013). As for the other species, $P$. bilgineri is endemic to Turkey, and $P$. peshmenii is distributed in Turkey and Iran. In the present study, P. scilloides, $P$. bilgineri and $P$. peshmenii are compared anatomically and it is aimed at contributing to the taxonomic separation of the species. In addition, the anatomical properties of the Puschkinia taxa and the taxonomically closely related Scilla L. section Chionodoxa Boiss. and Scilla bifolia L. taxa are also discussed.

\section{Materials and methods}

\section{Study area}

The species were collected from natural habitats in eastern and southeastern Anatolia (Fig. 1). The study area is situated in the Armenio-Iranian subregion of the Irano-Turanian phytogeographic region (Rivas-Martínez et al. 2004), and mostly has a continental semiarid climate with hot and

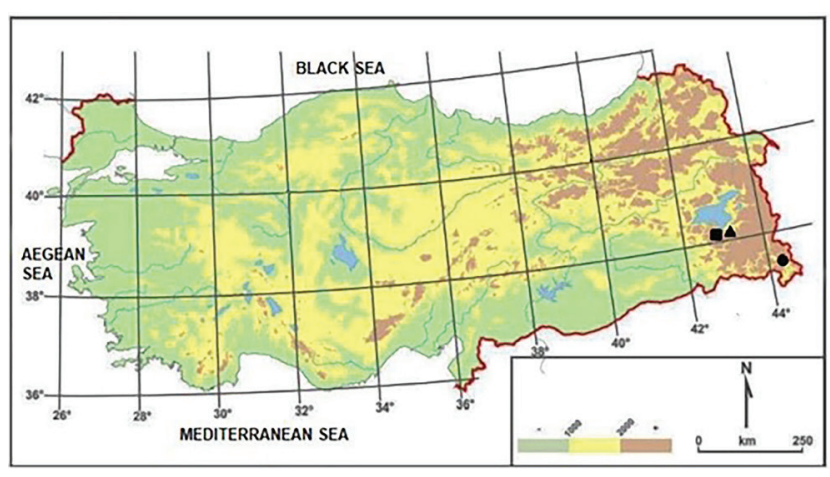

Fig. 1. Location of sampling sites of the Puschkinia species in Turkey: P. scilloides Adams ( $\mathbf{\Delta})$, P. bilgineri Yıldırım (•), P. peshmenii Rix et B. Mathew $(\bullet)$.

dry summers, and cold and snowy winters. Puschkinia bilgineri (Fig. 2A) was gathered from Van Province, Kavuşşahap mountain chain, at Karabet Gateway, alpine mountain meadows and mountain slopes, from 2885-3000 m a.s.l. (type locality). Puschkinia peshmenii (Fig. 2B, C) was collected from Hakkari Province, near the Yüksekova district, in the gorge leading into the valley from the west, among dwarf shrubs, from 1850-1900 m a.s.l. (type locality). Puschkinia scilloides (Fig. 2D) was gathered from Van Province,

\footnotetext{
* Corresponding author e-mail: kadriyeyetisen@gmail.com
} 


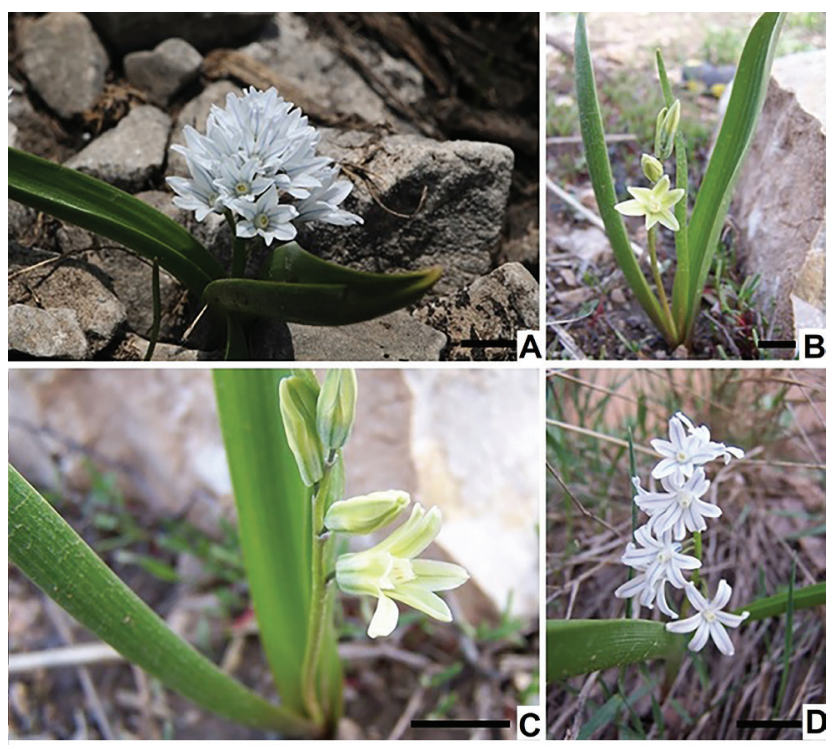

Fig. 2. Habitus of the Puschkinia species: P. bilgineri (A), P. peshmenii (B, C), P. scilloides (D). Scale bar $=1 \mathrm{~cm}$.

Gevaş district, Artos Mountain, opening slopes and plateau, from $2400-2550 \mathrm{~m}$ a.s.l.

\section{Sampling}

For the anatomical studies, the plant specimens were fixed in $70 \%$ ethanol. Ten specimens of each species were studied. The paraffin method (Algan 1981) was used for preparing cross-sections of the root, scape, and leaves of the species. Transverse sections of $15-20 \mu \mathrm{m}$ were made with a sliding microtome and stained with safranin-fast green. Measurements of the root and stem, and the leaf cell sizes of the species were taken using an ocular-micrometer and photographed with a motorized Leica DM 3000 microscope. The minimum, maximum, mean, and standard deviation were determined and are shown in Tab. 1. Fifteen cross-sections from each plant were made for each measurement (Tab. 1).

\section{Results}

Root

The rhizodermis, which consisted of elongated cells, was single-layered on the outer surface of the root in all of the species. There was no cuticle layer on the hypodermal cells. The cortex consisted of 6-8, 6-9, and 6-10 layered parenchymatous cells with intercellular spaces in $P$. scilloides, $P$. bilgineri, and P. peshmenii, respectively (Fig. 3A, C, F). The endodermis cell wall of all of the species was thick on all four sides. On the inside of the endodermis and adjacent to it was the cylinder of parenchyma cells called the pericycle in all of the studied species. The pericycle was 1 cell wide and consisted of thin-walled cells. Puschkinia scilloides had 1-2 metaxylem-vessels in the center of the root while P. bilgineri and $P$. peshmenii had just one. There were four xylem strands on the midpoint of the vascular cylinder in all of the spe-

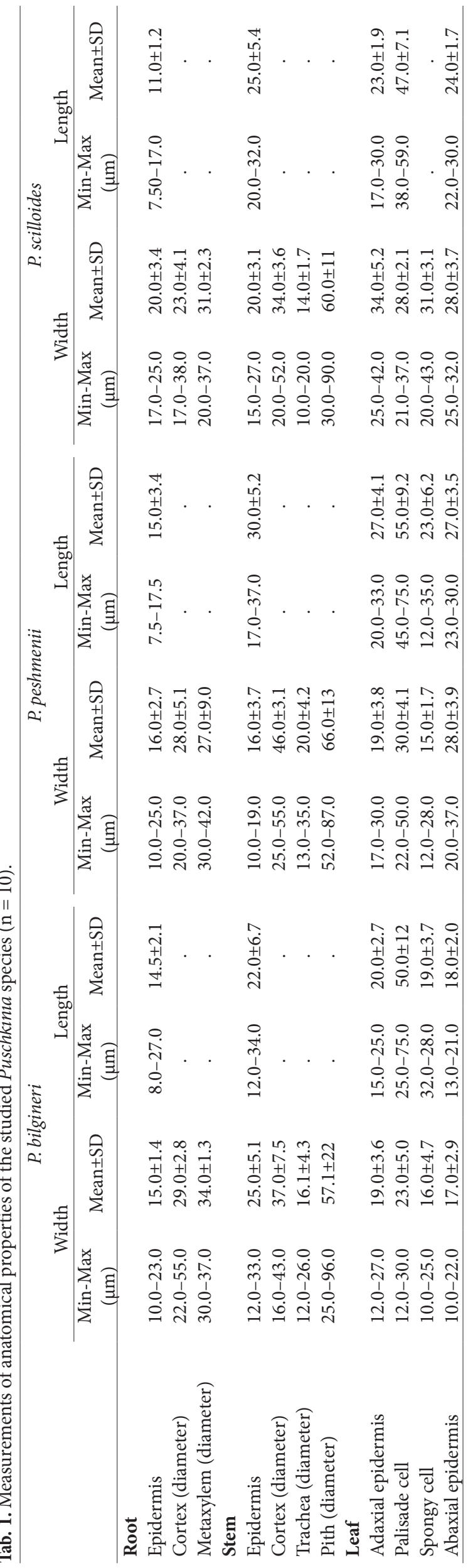

ACTA BOT. CROAT. 79 (1), 2020 


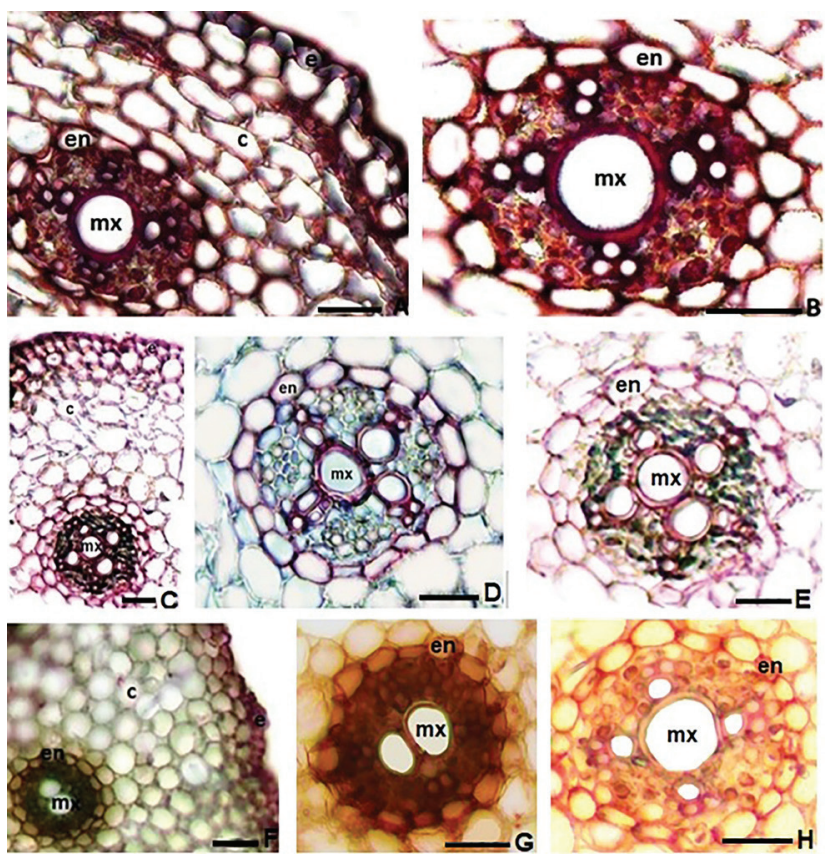

Fig. 3. Root cross-sections of the Puschkinia species: P. bilgineri (A, B), P. peshmenii (C, D, E), P. scilloides (F, G, H). c - cortex, e epidermis, en - endodermis, $\mathrm{mx}-$ metaxylem. Scale bar $=40 \mu \mathrm{m}$.

cies root cross-sections (Fig. 3B, D, E, G, H). Needle-shaped raphide crystals were present in the root cortex of $P$. scilloides and P. bilgineri.

\section{Scape}

A very thick cuticle layer covered the scape epidermis in all of the studied species. The cortex was composed of 6-9, 5-8, and 4-7 layered thin-walled, circular parenchyma cells with intercellular spaces in $P$. scilloides, $P$. bilgineri and $P$. peshmenii, respectively, under the epidermis (Fig. 4A, C, E). In P. scilloides, 23-29 collateral vascular bundles with thickwalled cells were arranged in 3 rings, while in P. bilgineri there were 16-20 vascular bundles arranged in 3 rings, and in P. peshmenii, there were 14-17 vascular bundles arranged in two rings. In $P$. peshmenii, a 1-3 cell lined collenchyma layer was present, whereas a $3-5$ cell lined layer was present in the other two species. There were pith cells in the center of the scape in all of the species (Fig. 4).

\section{Leaf}

Leaf anatomy was quite similar in all of the studied species. The epidermis comprised a single layer of cells covering both the abaxial and adaxial surfaces of the leaf, where there was a thick cuticle layer in all of the species. Outward epidermis cell protrusions were present at the ends of the leaves with, respectively 4-7, 3-5, and 3-6 in P. scilloides, P. bilgineri and P. peshmenii (Fig. 5G, J). Two regions of the mesophyll were distinguishable, and the adaxial and abaxial palisade parenchyma consisted of a rectangle, and ovalshaped cells were arranged in 2-3 rows in all of the species. The middle region consisted of loosely arranged spongy pa-

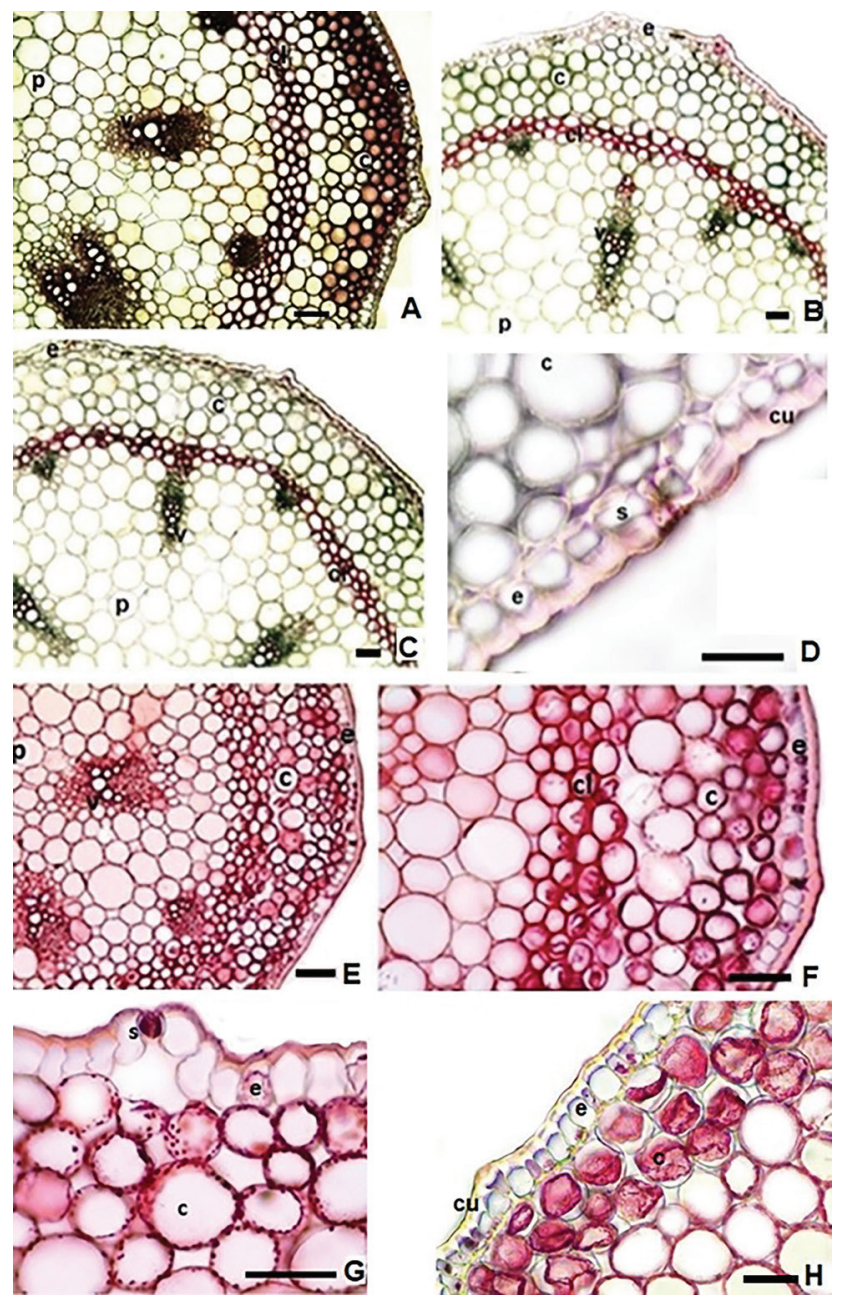

Fig. 4. Scape cross-sections of the Puschkinia species: P. bilgineri (A), P. peshmenii (B, C, D), P. scilloides (E, F, G, H). c - cortex, $\mathrm{cl}$ - collenchyma, $\mathrm{cu}$ - cuticle, e - epidermis, $\mathrm{p}$ - pith, $\mathrm{s}$ - stoma, $\mathrm{v}$ - vascular bundle. Scale bar $=40 \mu \mathrm{m}$.

renchyma cells with abundant air spaces between them in all of the taxa. The raphides present in the mesophyll of $P$. peshmenii were different from those in the other species.

The vascular bundles were arranged regularly in the center of the mesophyll in all of the species (Fig. 5). When the anatomical measurements were taken, the cell widths and lengths were generally close to each other. The measured values are detailed in the Tab. 1.

\section{Discussion}

When the anatomical features of the roots were compared, it was understood that $P$. scilloides differed from the other species by its $1-2$ metaxylem. When the scape properties were considered, the vascular bundles were arranged in two rings in $P$. peshmenii, while the other species had three rings and the number of vascular bundles in the species differed. The scape epidermis cells protruded outward in $P$. peshmenii, while they were almost non-existent in the other Puschkinia species. Scape cortex and pith cell measurements of $P$. peshmenii are bigger than the other two species. Leaf 

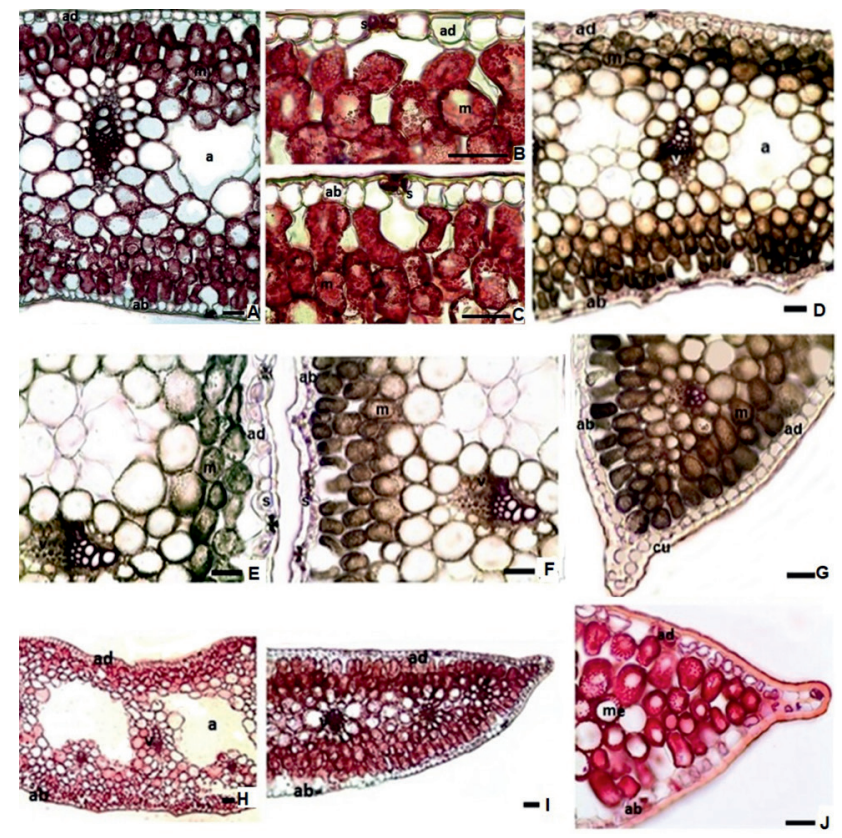

Fig. 5. Leaves cross-sections of Puschkinia species: P. bilgineri (A, B, C), P. peshmenii (D, E, F, G), P. scilloides (H, I, J). a - aerenchyma, $\mathrm{ab}$ - abaxial epidermis, ad - adaxial epidermis, $\mathrm{cu}$ - cuticle, $\mathrm{m}$ mesophyll, $\mathrm{s}-$ stoma, $\mathrm{v}-$ vascular bundle. Scale bar $=40 \mu \mathrm{m}$.

spongy cells of $P$. scilloides are larger than in the other two species (Tab. 1). The location and type of crystals in a plant are taxonomically important (Metcalfe and Chalk 1983, Fahn 1990). In this study, needle-shaped crystals were pres-

\section{References}

Algan, G., 1981: Microtechnics for plant tissues. PhD Thesis. Firat University, Faculty of Science, Istanbul, Turkey (in Turkish).

Almeida da Silva, R., Rosselló, J.A., 1990: Anatomical studies on the Scilla verna (Hyacinthaceae) complex. Israel Journal of Plant Sciences 47, 103-110.

Edmondson, J., 1984: Puschkinia Adams. In: Davis, P.H. (ed.), Flora of Turkey and the East Aegean islands 8, 226-227. Edinburgh Univeristy Press, Edinburgh.

Fahn, A., 1990: Plant Anatomy. $4^{\text {th }}$ ed. Pergamon Press, Oxford, New York.

Metcalfe, C.R., Chalk, L., 1983: Anatomy of the Dicotyledons. Vol. 1. Oxford University Press, Oxford.

Rivas-Martínez, S., Penas, A., Díaz, T.E., 2004: Mapa Biogeográfico de Europa. Servicio Cartográfico de la Universidad de León, España. Retrieved December 24, 2019 from http://webs. ucm.es/info/cif/form/maps.htm

Rix, M., Mathew, B., 2007: 582. Puschkinia peshmenii. Curtis's Botanical Magazine 24, 54-57. ent in the root cross-sections of $P$. scilloides and P. bilgineri, but the presence of raphide crystals in the mesophyll layer of the leaves of $P$. peshmenii distinguished this species from the others. The differences in the number of vascular bundles in the scape, the presence of raphide crystals, and the number of protruding epidermis cells at the tips of the leaves can be used to differentiate species of the genus Puschkinia.

These taxa are known to be taxonomically closely related to Scilla section Chionodoxa and Scilla bifolia taxa in Turkey (Ylldırım et al. 2017). The number of metaxylems in the root of Scilla taxa was higher than that in species of Puschkinia. Disintegration areas in the scape pith of the Scilla taxa were wider than that of the genus Puschkinia. A single-layered epidermis formed projections that formed longitudinal ribs in all of the taxa, except Scilla $\times$ allenii in the scape. These protrusions were present in the endemic P. peshmenii scape, but were almost non-existent in other Puschkinia species. Hyacinthoides Heist. ex Fabr. and Scilla taxa generally have aerenchyma cavities in the leaf mesophyll (Almeida da Silva and Rosselló 1990). We also observed aerenchyma cavities in the leaves of studied Scilla and Puschkinia taxa. Needleshaped raphide crystals were present in all three species of Puschkinia. In the studies carried out previously, such crystals were found in the leaves and stems of Scilla taxa (Satil and Akan 2006, Yildirım et al. 2017). In the three Puschkinia species, 3-7 epidermis cells protruded outwardly at the tip of the leaves. Such protrusions were not observed in the studied Scilla taxa (Yıldırım et al. 2017). This feature can be used to distinguish between the two genera.

Satil, F., Akan, H., 2006: Anatomical investigations on some endemic and rare geophytes from the Liliaceae family. Ekoloji 58, 21-27 (in Turkish).

Yıldırım, H., 2012: Puschkinia Adams. In: Güner, A., Aslan, S., Ekim, T., Vural, M. ve Babaç, M.T. (eds.), Turkey Plant List (Vascular Plants). Nezahat Gökyiğit Botanical Garden and Flora Research Association Publication, Istanbul (in Turkish).

Ylldırım, H., 2013: Domestic distribution and species variation limits of Puschkinia scilloides Adams (Asparagaceae/Liliaceae) in Turkey. Manas Journal of Agriculture and Life Sciences 3, 7-12 (in Turkish).

Yıldırım, H., 2014: Puschkinia bilgineri (Asparagaceae subfamily Scilloideae): A new species Puschkinia Adams from the eastern Anatolia region. Bağbahçe Bilim Dergisi 1, 1-10 (in Turkish).

Yıldırım, H., Yetișen, K., Özdemir, A., Özdemir, C., 2017: An anatomical study of Scilla (Scilloideae) Section Chionodoxa and Scilla bifolia in Turkey. Plantha Daninha 35. 